\title{
Food poisonings in Brazil - the impacts of the pandemic and its prevention
}

\section{perspectives}

\author{
Intoxicações alimentares no Brasil - os impactos da pandemia e suas perspectivas para a prevenção \\ Intoxicación alimentaria en Brasil - los impactos de la pandemia y sus perspectivas de prevención
}

Received: 09/30/2021 | Reviewed: 10/06/2021 | Accept: 10/15/2021| Published: 10/17/2021

\author{
Sabrina Fernandes Rosa \\ ORCID: https://orcid.org/0000-0002-4809-3950 \\ Centro Universitário FUNVIC, Brazil \\ E-mail: sabrina.01010474.pinda@unifunvic.edu.br \\ Maria Laura Costa Araújo \\ ORCID: https://orcid.org/0000-0002-2869-1056 \\ Centro Universitário FUNVIC, Brazil \\ E-mail: maria.01010165.pinda@unifunvic.edu.br \\ Matheus Diniz Gonçalves Coêlho \\ ORCID: https://orcid.org/0000-0002-7903-1429 \\ Centro Universitário FUNVIC, Brazil \\ E-mail: profmatheuscoelho@gmail.com
}

\begin{abstract}
This study aimed to describe the epidemiological profile of food poisoning in Brazil with its trends and prospects for prevention, between the years 2016 and 2020. A cross-sectional, retrospective study with a quantitative approach was developed, the data for the research were taken from official government websites, namely: SINITOX (National System of Toxic-Pharmacological Information), DATASUS and IBGE (Brazilian Institute of Geography and Statistics). It became evident that a significant and sharp decrease in cases of food poisoning in Brazil and in its five socio-political regions $(\mathrm{p}<0.0001)$ in the year 2020, such fact being probably related to the advent of the COVID-19 pandemic. Regarding the occurrence of food poisoning by gender there was predominance in males with a sharp and significant decrease in the year 2020 for both genders. The age group between 15-19 years was the most prevalent, followed by children under 1 year old. Thus, it can be concluded that food poisoning is closely related to food consumption outside the home, reinforcing the importance of the professional nutritionist as a propagator of good hygiene, handling, and healthy eating practices.
\end{abstract}

Keywords: Food poisoning; Occurrence; Brazil.

\section{Resumo}

Este estudo teve como objetivo descrever o perfil epidemiológico das intoxicações alimentares no Brasil com suas tendências e perspectivas de prevenção, entre os anos de 2016 e 2020. Foi desenvolvido um estudo transversal, retrospectivo com abordagem quantitativa, cujos dados para a pesquisa foram retirados de sites oficiais do governo, a saber: SINITOX (Sistema Nacional de Informações Tóxico-Farmacológicas), DATASUS e IBGE (Instituto Brasileiro de Geografia e Estatística). Evidenciou-se uma diminuição significativa e acentuada dos casos de intoxicações alimentares no Brasil e em suas cinco regiões sociopolíticas ( $p<0,0001$ ) no ano de 2020 , estando tal fato provavelmente relacionado ao advento da pandemia COVID-19. Em relação à ocorrência de intoxicações alimentares por gênero houve predomínio no sexo masculino com queda acentuada e significativa no ano de 2020 para ambos os sexos. A faixa etária de 15 a 19 anos foi a mais prevalente, seguida pelas crianças menores de 1 ano. Assim, pode-se concluir que a intoxicação alimentar está intimamente relacionada ao consumo alimentar fora do domicílio, reforçando a importância do profissional nutricionista como propagador de boas práticas de higiene, manuseio e alimentação saudável.

Palavras-chave: Intoxicação alimentar; Ocorrência; Brasil.

\section{Resumen}

Este estudio tuvo como objetivo describir el perfil epidemiológico de la intoxicación alimentaria en Brasil con sus tendencias y perspectivas de prevención, entre los años 2016 y 2020. Se desarrolló un estudio transversal, retrospectivo con enfoque cuantitativo, cuyos datos para la investigación fueron tomados de sitios web del gobierno. funcionarios, a saber: SINITOX (Sistema Nacional de Información Toxicológica-Farmacológica), DATASUS e IBGE (Instituto Brasileño de Geografía y Estadística). Hubo una disminución significativa y acentuada de casos de intoxicación alimentaria en Brasil y en sus cinco regiones sociopolíticas ( $<<0,0001)$ en 2020, y este hecho probablemente esté relacionado con el advenimiento de la pandemia COVID-19. En cuanto a la ocurrencia de 
intoxicaciones alimentarias por género, hubo predominio en el sexo masculino, con un descenso marcado y significativo en 2020 para ambos sexos. El grupo de edad de 15 a 19 años fue el más prevalente, seguido de los menores de 1 año. Así, se puede concluir que la intoxicación alimentaria está estrechamente relacionada con el consumo de alimentos fuera del hogar, reforzando la importancia del nutricionista profesional como propagador de buenas prácticas de higiene, manipulación y alimentación saludable.

Palabras clave: Intoxicación alimentaria; Ocurrencia; Brasil.

\section{Introduction}

In a scenario of constant globalization, it has become essential to verify the quality of food for the promotion and maintenance of individual health. According to the Ministry of Health, the number of occurrences caused by foodborne diseases (STD) has been growing considerably worldwide. Among the main causes are the high population growth, the poverty situation, the urbanization process, and the excessive consumption of processed foods. In addition to these factors, there is also a deficient monitoring of public and private agencies in controlling the quality of food offered to the population (Brasil, 2010).

Currently, the habit of eating meals in street food stores, such as snack carts for example, is growing every day, and consequently so are the cases of food poisoning. Any carelessness during the manipulation/cooking of food can result in serious physiological and pathological complications for consumers (Casemiro \& Martins, 2016; Pandolfi, Moreira \& Teixeira, 2020).

In general, all foods are susceptible to contamination by various etiological agents, since they have intrinsic factors such as $\mathrm{pH}$ and water activity and extrinsic factors such as temperature, relative humidity (RH) and presence of gases, which favor such infections (Hoffman, 2001).

Among the most common parasites are fungi that produce mycotoxins harmful to the body, the most frequent are those of the genus Aspergillus, Fusarium, and Penicillium. However, bacterial infections are the main responsible for cases of food poisoning, the most frequent are Salmonella spp, S. enteritidis, S. infantis, and S. Braenderup (Almeida et al., 2008).

Ty of the manifestations depends on factors such as the virulence of the etiological agent, the inoculum of the infection, and the immunological capacity of the individual. The symptoms can be easily confused with other pathologies, so there is some difficulty in identifying the vehicle of contamination. Thus, it is of fundamental importance to know how to diagnose it for a specific intervention/treatment in an efficient way and as soon as possible. Besides the difficulties in clinical care, it is important to emphasize that infected people only seek care when the condition is already in a severe state, leading to an underreporting of cases, hindering data collection, and favoring the advance of new unknown agents (Brasil, 2009).

Epidemiological surveillance is extremely important to contain outbreaks of ATD. Beginning in 1999, the system has several steps to verify the information. The investigations begin through the notifications acquired by the Ministry of Health and within 7 days are recorded in the Sistema de Informações de Agravos de Notificações (Sinan). After this process, samples are collected and sent to laboratories for diagnosis, and the results are used to create reports, bulletins, and prevention and control measures. In Brazil in 2000, 545 outbreaks were identified, 31,943 thousand people exposed, 9,613 patients, 4 deaths, and a lethality rate of $0.04 \%$. In 2017,441 outbreaks were identified, 15,287 people exposed, 6,559 patients, 8 deaths, and a lethality rate of $0.12 \%$. Therefore, a considerable decrease in the number of cases in recent years is noted; some factors, such as improvements in the health system, basic sanitation, prevention measures, and greater control, are mainly responsible for these declines (Brasil, 2018).

However, despite the advances, it is possible to note that there is still an increase in the number of deaths and the lethality rate, showing that food poisoning is still a serious public health problem in Brazil. Given the above, the present study aimed to identify and evaluate sociodemographic and epidemiological aspects related to food poisoning, its prospects for prevention and how the Pandemic due to COVID-19 influenced these indicators. 


\section{Methodology}

To outline this research, an epidemiological analysis of time series was carried out, according to the methodology suggested by Latorre and Cardoso (2001), who, in an introductory article on temporal analyses, not only defined the concept of time series, as being a data string obtained at regular intervals of time during a specific period, as well as schematized in a simplified way the concept of analysis of a time series, according to which the studied phenomenon is first modeled for, from there, describe the behavior of the series, make estimates and, finally, evaluate which factors influenced the behavior of that series.

This is a cross-sectional, retrospective study with a quantitative approach, in which sociodemographic data of Brazil and its socio-political regions (South, Southeast, Midwest, North, and Northeast) were analyzed regarding the epidemiological behavior of food poisoning. The data survey was conducted using as a research source official government websites, in the period from 2016 to 2020, namely: SINITOX (National System of Toxic-Pharmacological Information), DATASUS and IBGE (Brazilian Institute of Geography and Statistics), to assess the prevalence of poisonings due to food ingestion and the associated factors. The variables analyzed were: gender, age group, and zone of occurrence. To collect the variables: gender, age group, and zone of occurrence, information available at DATASUS was used, which was processed and statistically analyzed. Considering the fact that there is no precise source that defines exactly which foods caused the poisonings, in order to provide a basis for the definition of strictly specific prevention measures, such information was estimated based on reports in scientific articles related to the theme, and, for this, an extensive bibliographic search was made in scientific literature, in the main databases, namely LILACS, Medline and Google Scholar, using as keywords: food poisoning, occurrence, Brazil. Statistical evaluations were performed by determining variance and significant differences between the means obtained, using as a support tool the software bioestat 5.0. The interpretation of the information was performed according to the statistics presented for each variable, seeking possible hypotheses for the findings in the scientific literature on food poisoning in Brazil and the impacts of the pandemic.

\section{Results}

The incidence rates of food poisoning in Brazil and its five socio-political areas during the period from 2016 to 2020 are shown in Figures 1 to 6.

Figure 1. Incidence rate of food poisoning in Brazil (2016 to 2020).

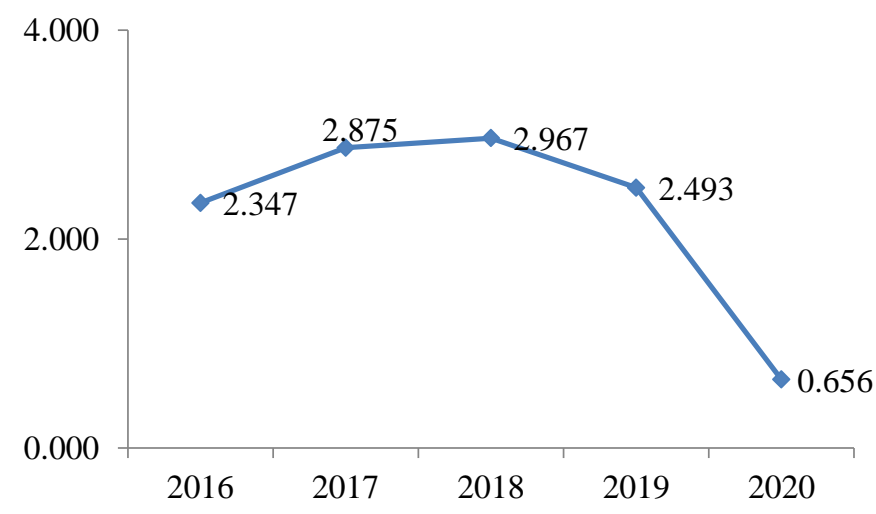

There was no significant difference in the incidence rate observed in the 05 years. Source: Authors. 
Figure 2. Incidence rate of food poisoning in the region Southeast region of Brazil (2016 to 2020).

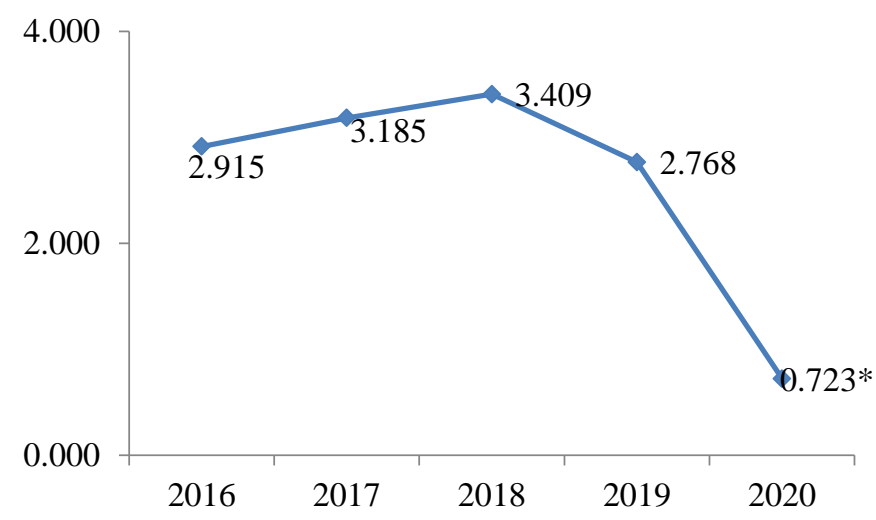

* significant difference $(\mathrm{G} / \mathrm{p}$ test $<0.0001)$ in relation to the other years. Source: Authors.

Figure 3. Incidence rate of food poisoning in the region South of Brazil (2016 to 2020).

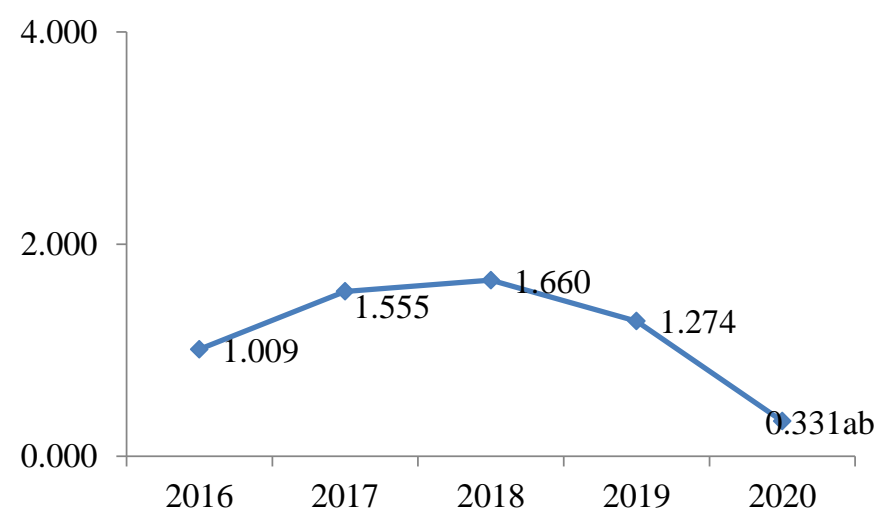

a - significant difference (G test/p<0.0001) compared to the years 2017 to 2019 . b- significant difference $(\mathrm{G}$ test $/ \mathrm{p}<0.01)$ in relation to the year 2016. Source: Authors.

Figure 4. Incidence rate of food poisoning in the region North region of Brazil (2016 to 2020).

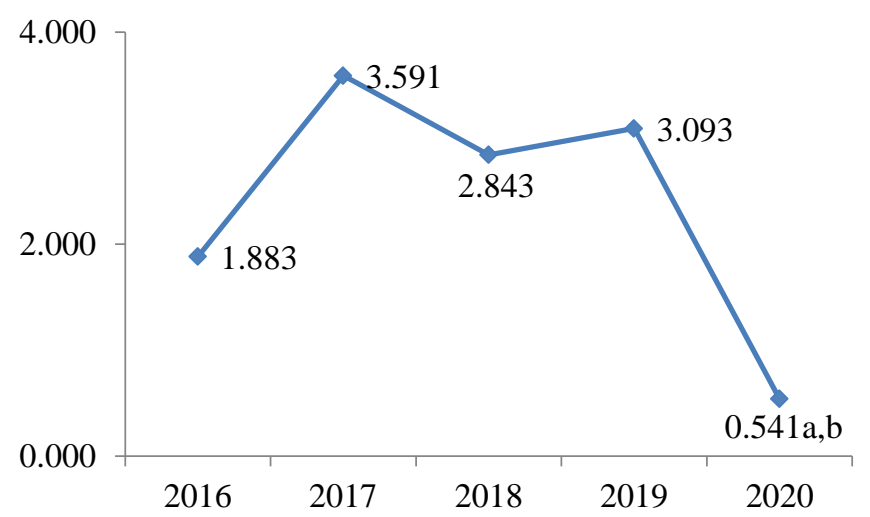

a - significant difference (G test/p<0.0001) compared to the years 2017 to 2019 . b- significant difference $(\mathrm{G}$ test $/ \mathrm{p}<0.01)$ in relation to the year 2016. Source: Authors. 
Figure 5. Incidence rate of food poisoning in the region Northeast region of Brazil (2016 to 2020).

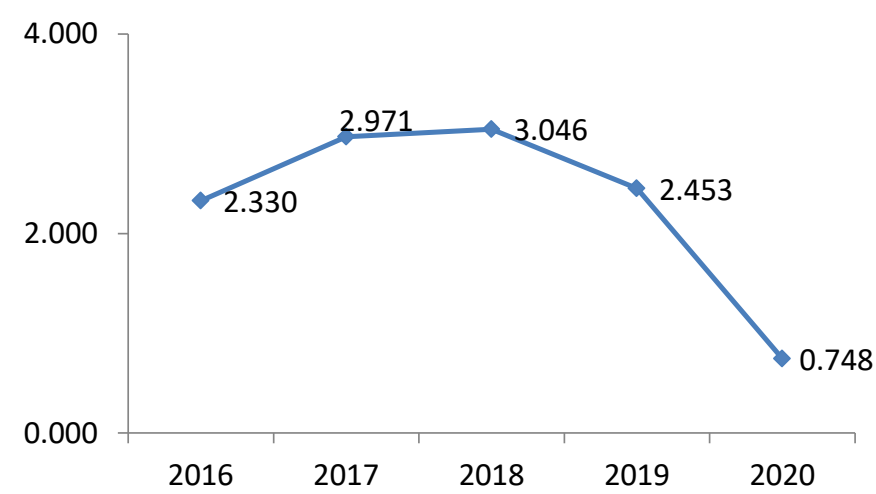

* significant difference $(\mathrm{G} / \mathrm{p}$ test $<0.0001)$ in relation to the other years. Source: Authors.

Figure 6. Incidence rate of food poisoning in the region Midwestern region of Brazil (2016 to 2020).

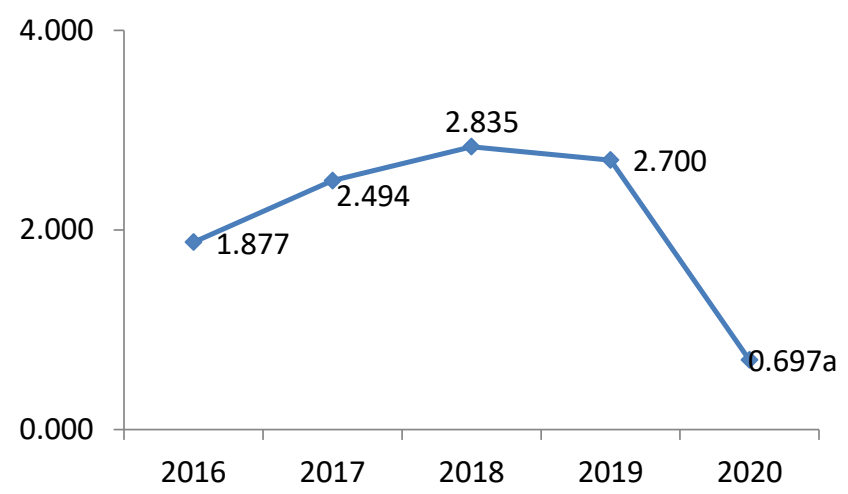

* significant difference $(\mathrm{G} / \mathrm{p}$ test $<0.01)$ in relation to the years 2017 to 2019 . Source: Authors.

The incidence rates of food poisoning related to genders during the period from 2016 to 2020 are shown in Figure 7.

Figure 7. Incidence rates of food poisoning in Brazil, between the years 2016 and 2020, in relation to gender.

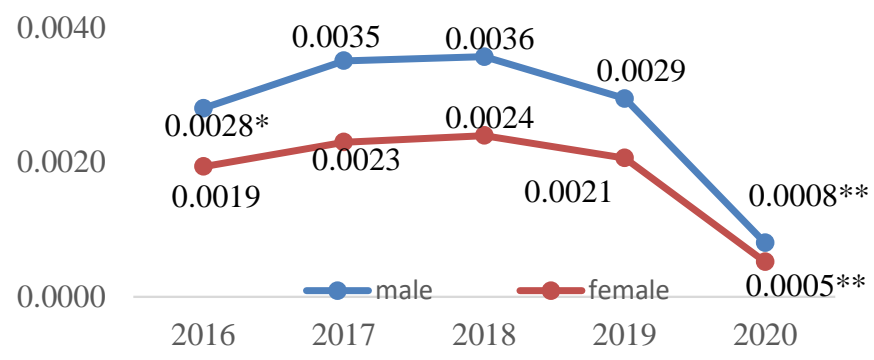

* significant difference in relation to the incidence rate of women, in the same year. ** significant difference in relation to the incidence in the same gender, in other years. Source: Authors.

The incidence rates of food poisoning related to age groups from $<1$ year to $>80$ years, during the period from 2016 to 2020, are shown in Figures 8 to 12 , observing a predominance ( $\mathrm{G}$ test / $\mathrm{P}<0.0001$ ) in the age group of 15 to 19 years in all years. 
Figure 8. Incidence rate of food poisoning in Brazil according to age, 2016.

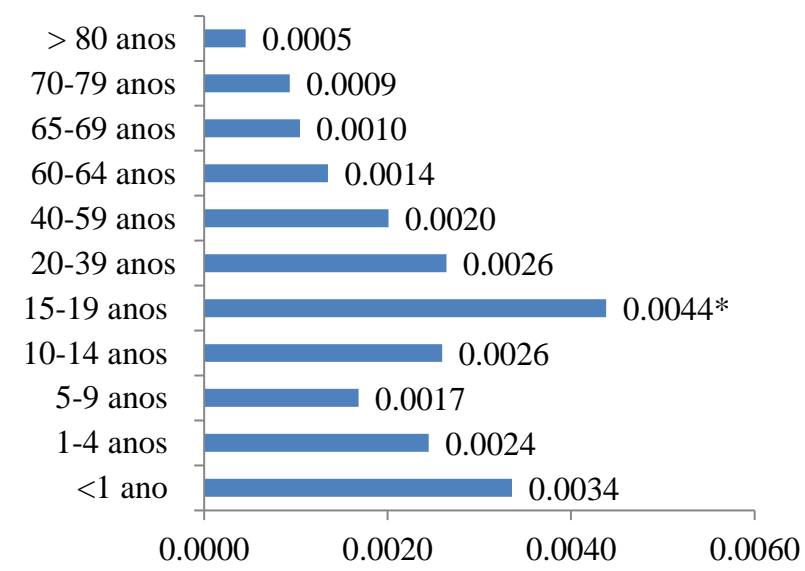

* significant difference in relation to the other age groups. Source: Authors.

Figure 9. Incidence rate of food poisoning in Brazil according to age, 2017.

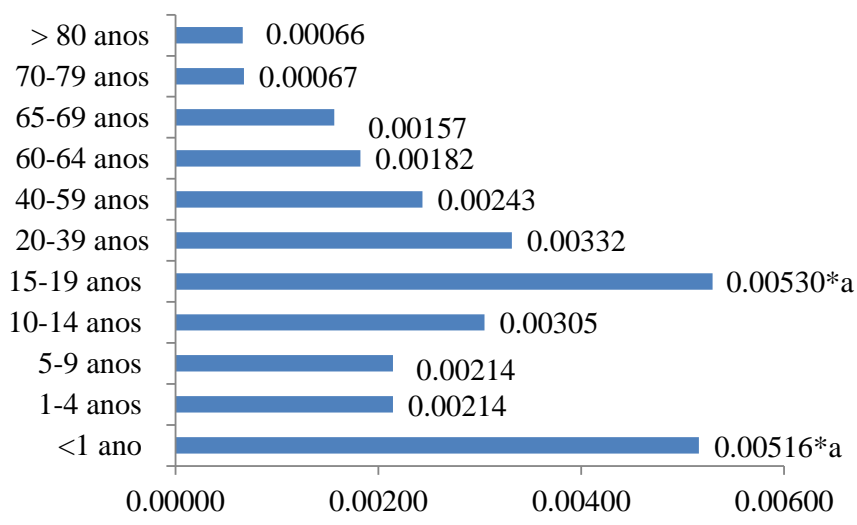

* significant difference in relation to the other age groups. a- no significant difference. Source: Authors.

Figure 10. Incidence rate of food poisoning in Brazil according to age, 2018.

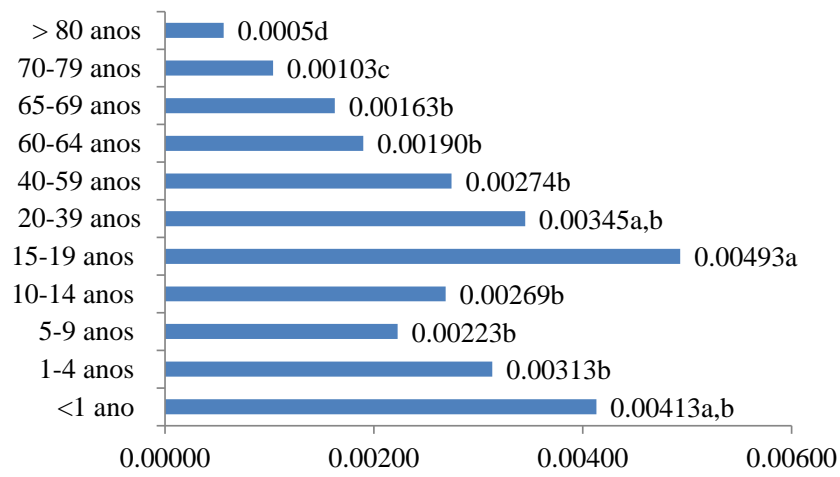

a,b,c,d - different letters imply significant difference $(\mathrm{p}<0.01)$. Source: Authors. 
Figure 11. Incidence rate of food poisoning in Brazil according to age, 2019.

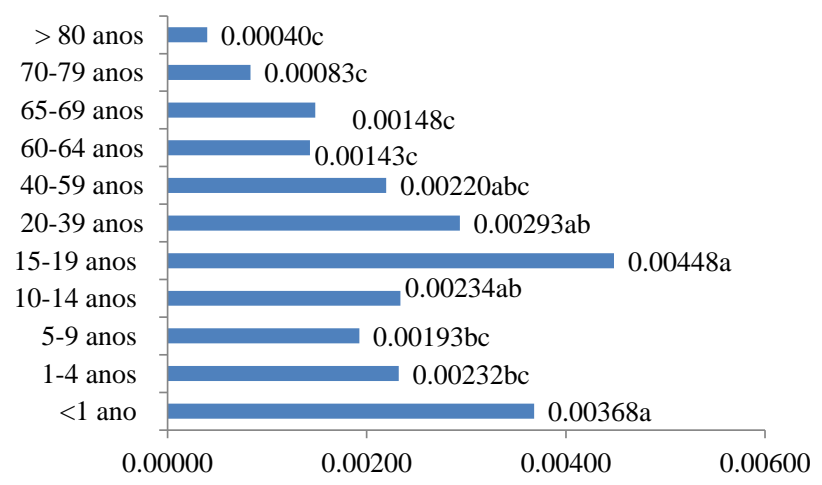

a,b,c - different letters imply significant difference $(\mathrm{p}<0.01)$. Source: Authors.

Figure 12. Incidence rate of food poisoning in Brazil according to age, 2020.

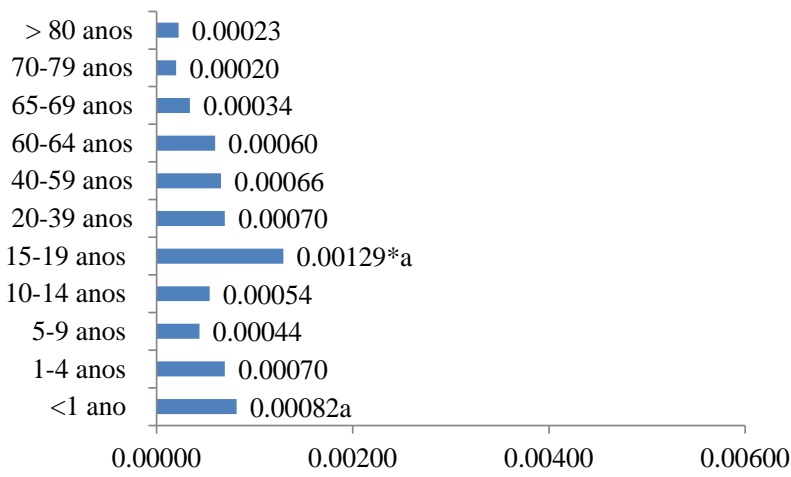

* significant difference in relation to the other age groups (except <1 year). a- no significant difference. Source: Authors.

Considering the predominance of food poisoning in the 15-19 age group, a comparison of the incidence of food poisoning throughout the historical series was performed, observing that there was a significant decrease in the number of cases in the year 2020, according to Figure 13.

Figure 13. Incidence of food poisoning in the age group from 15 to 19 years old, in Brazil, between the years 2016 to 2020.

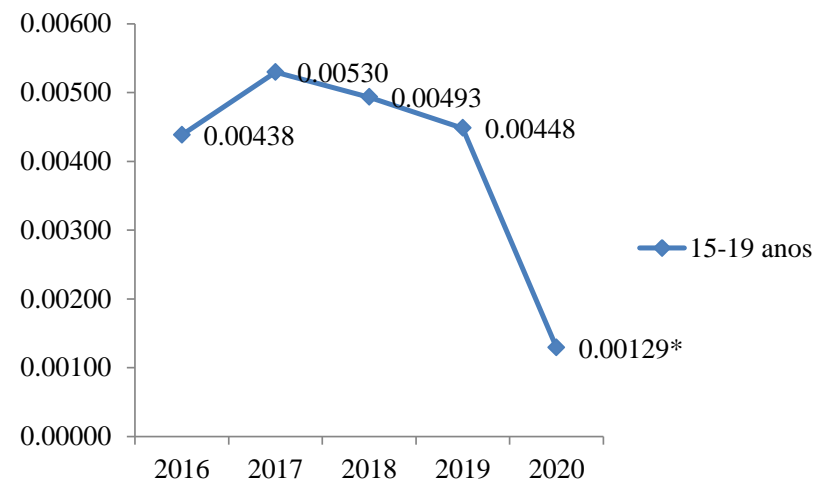

* significant difference (G-test/ $\mathrm{p}<0.0001)$ compared to the incidence rates observed in the other years of the historical series. Source: Authors. 


\section{Discussion}

When observing the results regarding the incidence rate of food poisoning in Brazil and its five socio-political regions, it is possible to infer that there was a significant $(\mathrm{p}<0.0001 /$ Chi-square) and sharp decrease in the number of cases in the year 2020 in detriment to the rates observed in the other years analyzed in the historical series. This downward trend was present both in Brazil as a whole and in all its regions.

One of the factors that may have markedly influenced this decrease in the incidence rate of food poisoning observed may be related to the advent of the COVID-19 pandemic. The high transmissibility and severity of the infection caused by this virus led to the implementation of preventive measures worldwide, based on the obligation of social detachment and the cancellation of most economic activities, allowing only the activities considered essential, not including the operation of bars, restaurants and street food stores. In Brazil, the cancellation of such activities lasted for several months, having only been allowed again, albeit partially and with restrictions on the number of people, in the final months of 2020, causing the feeding of Brazilians to remain predominantly at home, a fact that may have influenced the reduction of some risk factors related to the form of preparation, display and distribution of food items in commercial establishments.

According to the Ministry of Health, the predominance of Foodborne Diseases (FTS) is closely related to the increased exposure of populations to foods intended for immediate collective consumption, the so-called fast food, as well as the consumption of food on public roads, the significant increase in the use of additives, the ease of movement of the population, and changes in eating habits (Brasil, 2010). Such evidence was emphasized by Magnoni et al. (2016), who evaluated data from the Epidemiological Surveillance Center (CVE) of the Health Secretariat of the State of São Paulo - SP, Brazil, and observed an increase in meals taken outside the home in the Brazilian population until 2015, and a correlation of this practice with an increase in the number of ATD cases.

According to data from the Household Budget Survey (POF) conducted by the Brazilian Institute of Geography and Statistics (IBGE), more than 30\% of the average family expenditure is spent on food outside the home (IBGE, 2019). Moreover, the business of selling food on the streets has been growing significantly in recent years, in which, facing a scenario of high unemployment, many people seek this type of service as an alternative source of income, a practice that alleviates family financial problems, but implies a greater risk of increased incidence of food poisoning.

According to Fonseca et al. (2018) there is significant evidence of health problems associated with the consumption of food sold on the street, due to poor infrastructure, lack of license to operate, noncompliance with legislation, and lack of surveillance by Health Surveillance, bringing serious concerns about the safety of these foods (Fonseca et al., 2018).

On the other hand, however, a recent survey conducted by NutriNet, an initiative of the Center for Epidemiological Research in Nutrition and Health at the University of São Paulo (Nupens/USP) shows that the pandemic favored healthy eating. The research began in January 2020 and intends to monitor 200 thousand Brazilians over the next 10 years, to observe the association of eating habits with the risks of developing chronic diseases. The indicators showed signs that the pandemic had beneficial effects on the eating habits of Brazilians, who began to regularly consume more healthy foods such as beans, fruits, and vegetables (Steele et al., 2020).

Thus, the direct correlation between food consumption in food establishments and the occurrence of ATD is highlighted, since in periods of greater restriction during the pandemic, exposure to this risk factor decreased, since the mandatory need for home confinement brought to light the practice of food preparation at home, as well as self-care, with better hygiene of food, extra care with the way it is prepared and improvement in eating habits. Added to these factors is the decentralized demand for food production, so that in each residence a restricted amount was produced, different from what occurs in food establishments, maximizing the preparation of meals with more care and diligence.

With regard to the occurrence of food poisoning by gender, we can observe a predominance in males, with a sharp 
and significant decrease in the year 2020 for both genders. This more evident trend in the male public can be attributed to several factors. A study conducted by Assumpção et al. (2017) showed that the quality of the diet of the female gender is of better quality than that of the male gender, the reason identified was that women make a greater consumption of fruits, vegetables, and eggs. In addition, the study also identified that women have a greater concern about the quality of food, read nutrition labels more and seek to take greater care in the selection and preparation of food. With regard to the consumption of food outside the home, men stand out compared to women, showing a higher percentage consumption of pasta, cakes, cookies, sausages, pizzas, baked and fried snacks and sandwiches (Bezerra et al., 2013; Masella \& Malorni, 2017). Finally, it was concluded by Bernardes et al. (2016) that the understanding of what it is to be a man and the construction of male subjectivity hinder self-care practices, which makes them easily subject to the risks of a disease that could be avoided.

Finally, regarding the occurrence of poisonings by age, it was observed a predominance in the 15 to 19 -year-old age group throughout the analyzed period. In a study conducted by Esteves-Amaral et al. (2019), where food poisonings were investigated in the period from 2008 to 2016, a predominance in the 30 to 39 age group could be observed. Comparing these data with the present study, one can observe a change in the epidemiological profile of food poisoning. Such evidence, where adolescents are more susceptible to poisoning, can be explained. According to Lemos et al. (2005), in recent years the eating pattern of young people has changed. In a period of constant technological advances, they are increasingly seeking to live in groups, causing their behaviors to change. Thus, in this period, a rupture of standards is manifested, with rejection of the familiar food and imitation of the habits of the group in which they want to be accepted. It has become a common practice among young people to consume fast food, eat out of home, and prefer snacks and ready meals. Thus, since they are less concerned about what they consume, they end up becoming a public more exposed to food poisoning.

It also was observed a significant number of cases of food poisoning in the age group of individuals under 1 year of age. This is due to the wrong influence of complementary food introduction, caused by maternal beliefs and taboos. There are several factors that conflict with maternal decisions, and thus bring consequences for the child's health in the short and long term, leading to chronic diseases and food poisoning, causing damage to the child's diet. Therefore, it is worth emphasizing the importance of the professional nutritionist, promoting the child's health, encouraging and guiding mothers to an appropriate and correct introduction of food to their children (Martins \& Haack, 2012). Remembering also that exclusive breastfeeding during the first months of life is essential to prevent diseases in newborns and reduce the amount of infant mortality, due to its benefits that confer immunity and protect babies against infections (Newborns, 1995; Del Ciampo \& Del Ciampo, 2018).

\section{Conclusion}

It is evident, therefore, that there is a direct correlation between food poisoning and eating out. With the advent of the pandemic caused by the high transmissibility of COVID-19, it was possible to notice a sudden and accentuated drop in cases of food poisoning. This fact, closely related to home confinement and the new eating habits of Brazilians. Thus, it reinforces the importance of the nutritionist professional in reducing new occurrences of toxinfections by raising awareness about good handling practices, such as personal and food hygiene. In addition, it was possible to observe a low effectiveness of sanitary inspection services, since they have the duty to eliminate, reduce or prevent health risks and through actions to intervene in sanitary problems arising from the means of production, marketing or circulation of products.

Thus, this work hopes to have contributed to the study of food poisoning in Brazil, emphasizing the importance of proper food handling and how an effective sanitary inspection could reduce this problem. Finally, as suggestions for future researchers, further studies are needed to verify whether this behavior, related to food poisoning, will be maintained or set back again, with the return of economic activities in Brazil, as well as to better map the factors that lead to an increase in the number of cases of food poisoning, as a way of helping to minimize this important public health problem. 


\section{References}

Almeida, C. F. et al. (2008). Perfil epidemiológico das intoxicações alimentares notificadas no Centro de Atendimento Toxicológico de Campina Grande, Paraíba. Revista Brasileira de Epidemiologia, 11: 139-146.

Assumpção, D. et al. (2017). Diferenças entre homens e mulheres na qualidade da dieta: estudo de base populacional em Campinas, São Paulo. Ciência \& Saúde Coletiva, 22: 347-358.

Bernardes, A. F. M. et al. (2016). Alimentação saudável, cuidado e gênero: percepções de homens e mulheres da zona noroeste de Santos-SP. Demetra: Alimentação, Nutrição \& Saúde, 11(3): 559-573.

Bezerra, I. N. et al. (2013). Consumo de alimentos fora do domicílio no Brasil. Revista de Saúde Pública, 47: 200s-211s.

Brasil. (2009). Ministério da Saúde. Secretaria de Vigilância em Saúde. Departamento de Vigilância Epidemiológica. Guia de Vigilância Epidemiológica / Ministério da Saúde, Secretaria de Vigilância em Saúde, Departamento de Vigilância Epidemiológica. (7a ed.). Ministério da Saúde, 816 p. - (Série A. Normas e Manuais Técnicos).

Brasil. (2010). Ministério da Saúde. Secretaria de Vigilância em Saúde. Departamento de Vigilância Epidemiológica. Manual Integrado de Vigilância, prevenção e controle de doenças transmitidas por alimentos / Ministério da Saúde, Secretaria de Vigilância em Saúde, Departamento de Vigilância Epidemiológica - Brasília: Editora do Ministério da Saúde, 158 p.: il. - (Série A. Normas e Manuais Técnicos).

Brasil. (2018). Ministério da Saúde. Surtos de Doenças Transmissíveis por Alimentos no Brasil. Edição janeiro de 2018. https://portalarquivos2.saude.gov.br/images/pdf/2018/janeiro/17/Apresentacao-Surtos-DTA-2018.pdf.

Casemiro, L. P. \& Martins, A. L. O. (2016). Contamination prevalence of microbiological and parasitological mayonnaise ofhomemade marketed in hot-dog stands. Revista Brasileira de Análises Clínicas, 48(4):394-399.

Del Ciampo, L. A. \& Del Ciampo, I. R. L. (2018) Breasfeeding and benefits of lactation for women's health. Revista Brasileira de Ginecologia e Obstetrícia, 40:354-359.

Esteves-Amaral, F. L., Silva, E. F., Lima-Lacerda, F. A. \& Pinto, N. B. (2019). Análise retrospectiva dos casos de intoxicação humana por alimentos no Brasil no período de 2008 a 2016, Revinter, 12(1):48-59.

Fonseca, W. C. et al. (2018). Comida de rua: conhecimento dos consumidores sobre segurança dos alimentos e condições higienicossanitárias de pontos de venda em São Luís, MA. Higiene alimentar, 61-65.

Hoffman, F. L. (2001). Fatores limitantes à proliferação de microorganismos em alimentos. Brasil Alimentos, 9(1):23-30.

IBGE. (2019). Pesquisa de orçamentos familiares 2017-2018: Primeiros resultados /IBGE, Coordenação de Trabalho e Rendimento. IBGE, 69 p.

Latorre, M. R. D. O. \& Cardoso, M. R. A. (2001). Análises de séries temporais em epidemiologia: uma introdução sobre os aspectos metodológicos. Revista Brasileira de Epidemiologia, 4(3):145-152.

Lemos, M. C. M. \& Dallacosta, M. C. (2005). Hábitos alimentares de adolescentes: Conceitos e práticas. Arquivos de Ciências da Saúde Unipar, 9(1): 3-9.

Magnoni, D. et al. (2016). Segurança alimentar e informação nutricional podem reduzir a intoxicação alimentar na alimentação fora do lar. Revista Brasileira de Nutrição Clinica, 31(2): 91-6.

Martins, M. L. \& Haack, A. (2012). Conhecimentos maternos: influência na introdução da alimentação complementar. Comunicação em Ciências da Saúde, Brasília, 23(3): 263-270.

Masella, R. \& Malorni, W. (2017). Gender-related diferences in dietary habits. Clinical Management Issues. 11(2):59-62.

Newman, J. (1995). How Breast Milk Protects, and Jack Newman. Scientific American, 273(6):76-79.

Pandolfi, I. A. Moreira, L. Q. \& Teixeira, E. M. B. (2020). Segurança alimentar e serviços de alimentação-revisão de literatura. Brazilian Journal of Development, 6(7): 42237-42246.

Steele, E. M. et al. (2020). Changes in the diet in the NutriNet Brasil cohort under COVID-19. Revista de Saúde Pública, 54:91. 